\title{
Gaya Hidup Nongkrong di Kafe dan Perilaku Gosip sebagai Kontrol Sosial
}

\author{
Hangout Lifestyle in Cafe and Gossiping Behavior as Social Control
}

\author{
Alwazir Abdusshomad \\ Politeknik Penerbangan Indonesia Curug, Tangerang, Indonesia \\ alwazir@ppicurug.ac.id
}

Article history:

Submitted: November 10, 2020

Approved: June 2, 2021

Published: June 25, 2021

\begin{abstract}
This research relates to people's lifestyle generally in big cities, especially in Tangerang, a satellite city of Greater Jakarta. The problem raised here is how the lifestyle of hanging out in cafes can influence on society to practice gossiping behavior. This qualitative research done by case study on a number of targeted adult informants discovered that the lifestyle of hanging out at the cafe has become commonplace among the community, indicating that humans are social creatures. Hanging out activities that are intended to have fun and relax can trigger people to participate in gossiping behavior where the activity cannot be easily avoided from the existing environment. Besides the gossip activities seem to be fun and merely entertaining activities, found that the activities can be a social control for the community.
\end{abstract}

Keywords: gossip as social control; gossiping behavior; hanging out; social creature.

Abstrak: Penelitian ini berkaitan dengan gaya hidup masyarakat pada umumnya di kota-kota besar khususnya di Tangerang yang merupakan kota satelit Jabodetabek. Permasalahan yang diangkat di sini adalah bagaimana gaya hidup menongkrong di kafe dapat mempengaruhi masyarakat untuk mempraktikkan perilaku gosip. Penelitian kualitatif yang dilakukan dengan studi kasus pada sejumlah informan dewasa yang dibidik ini menemukan bahwa gaya hidup menongkrong di kafe sudah menjadi hal yang lumrah di kalangan masyarakat, menandakan bahwa manusia adalah makhluk sosial. Kegiatan nongkrong yang bertujuan untuk bersenangsenang dan bersantai dapat memicu masyarakat untuk ikut serta dalam perilaku gosip dimana kegiatan tersebut tidak dapat dengan mudah dihindari dari lingkungan yang ada. Selain kegiatan gosip yang terkesan menyenangkan dan hanya sekedar hiburan, ternyata kegiatan tersebut dapat menjadi kontrol sosial bagi masyarakat.

Kata kunci: gosip sebagai kontrol sosial; makhluk sosial; nongkrong; perilaku bergosip. 


\section{Pendahuluan}

Zaman modern merupakan masa adanya perubahan yang terjadi di seluruh dunia. Keadaan saat ini tentu saja berbeda dengan keadaan yang dahulu. Perubahan yang terjadi mempengaruhi pola hidup masyarakat di kemudian hari. Modernisasi mengubah kehidupan dalam pemenuhan kebutuhan hidup manusia dalam hal kemajuan teknologi yang semakin canggih. Kemajuan teknologi memberikan pengaruh besar terhadap masyarakat dalam hal sosial, ekonomi, dan budaya.

Pemenuhan kebutuhan hidup masyarakat yang meningkat maka meningkat pula gaya hidup masyarakat tersebut. Tingginya gaya hidup masyarakat menjadi perangkap bagi kehidupan manusia itu sendiri. Tak jarang masyarakat berlomba-lomba untuk mencapai kemewahan dan kesenangan duniawi dibandingkan dengan mengejar akhiratnya. Bagi sebagian orang, gaya hidup hedonis merupakan hal terpenting untuk dipenuhi dan mengikuti tren yang sedang hits merupakan suatu keharusan. Contohnya adalah mengikuti gaya berpakaian para selebritis atau selebgam. Gaya berpakaian masyarakat yang modern selalu dihubungkan dengan perkembangan zaman dimana mereka dianggap mampu mengikuti mode yang sedang tren. Sejatinya, manusia sejak kecil pasti menginginkan kesenangan hidup. ${ }^{1}$ Herlyana dalam penelitiannya menyatakan bahwa sebagian anak muda menyukai gaya hidup yang cenderung berorientasi pada nilai kebendaan dan kemewahan. ${ }^{2}$

Oleh karena itu, gaya hidup telah mengalami perubahan dan perkembangan. Jika dulu, masyarakat tidak selalu mementingkan urusan penampilan dan gaya hidup; saat ini kondisinya berbeda. Gaya hidup sudah mulai menjadi perhatian serius. Gaya hidup atau lifestyle berkaitan dengan bagaimana seseorang menghabiskan waktunya, apa yang terpenting di lingkungannya, dan apa yang dipikirkan tentang diri sendiri dan lingkungan sekitar. ${ }^{3}$ Salah satu bentuk gaya hidup yang cukup sering dianut adalah tentang busana yang membuat manusia selalu berlomba membeli pakaian yang sesuai dengan gaya yang diinginkan. ${ }^{4}$ Gaya hidup yang berlebihan sangat mengkhawatirkan ketika seseorang tidak mampu mengontrol diri sehingga menyebabkan seseorang memiliki perilaku konsumtif. Perilaku konsumtif mengakibatkan dampak buruk terhadap kemampuan finansial setiap individu, karena perilaku ini dapat dikatakan sebagai tindakan pemborosan yang dapat melampaui batas kemampuan seseorang.

Gaya hidup, saat ini, bukan hanya tentang masalah penampilan semata, tetapi aktivitas nongkrong pun menjadi tren masa kini bagi sebagian kalangan masyarakat untuk berkumpul dan melakukan kegiatan sebagai pengisi waktu luang. Namun, di sisi lain memiliki waktu luang dapat menimbulkan masalah baru bagi masyarakat. Mereka mencuri-curi waktu untuk melakukan kesenangan di luar rumah untuk mendapatkan hiburan. Kepadatan kegiatan setiap orang serta adanya perubahan kebiasaan di lingkungan tempatnya tinggal membuat seseorang akan beradaptasi dengan lingkungan baru tempatnya tinggal. Adaptasi terhadap lingkungan baru berfungsi untuk mendapatkan kenyamanan ketika berada di lingkungan baru. Dalam hal ini,

\footnotetext{
${ }^{1}$ Petr Kropotkin, "Ethics : Origin and Development” (London: George G. Harrap and Co., LTD., London, Calcutta, and Sydney 1924., 1922), 1-138, https://doi.org/10.1130/spe164-p1.

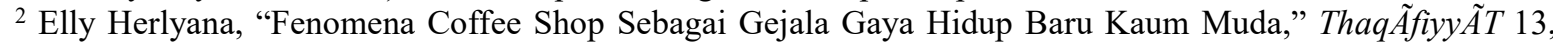
no. 1 (2012): 188-204.

${ }^{3}$ Donni Juni Priansa, Perilaku Konsumen Dalam Persaingan Bisnis Kontemporer (Bandung: Alfabeta, 2017).

${ }^{4}$ Ananda Vidyaratri Mega Pratiwi and Rizki Amalia Sholihah, "Evolusi Dan Eksistensi Model Abaya Pada Masa Modern Di Jazirah Arab," Al-Adabiya: Jurnal Kebudayaan Dan Keagamaan 15, no. 02 (December 12, 2020): 229-41, https://doi.org/10.37680/adabiya.v15i02.620.
} 
setiap orang dihadapkan dengan tantangan untuk mampu beradaptasi agar dapat bermanfaat di lingkungan barunya. ${ }^{5}$ Kemampuan untuk beradaptasi sangat penting karena hal tersebut menunjang seseorang untuk bersosialisasi dalam masyarakat di lingkungan sekitarnya. Dapat beradaptasi dengan baik di lingkungan baru menandakan semakin mudah seseorang diterima di lingkungannya. ${ }^{6}$

Menghilangkan rasa jenuh dan lelah setelah seharian bekerja membuat masyarakat urban mencari kegiatan atau hiburan di luar rumah, seperti pergi ke mall, berbelanja, menongkrong, atau sekedar bersantai dengan teman sejawat di kafe. Seiring dengan berkembang pesatnya suatu kota, maka lifestyle atau gaya hidup masyarakat milenial juga menunjukkan gejala perubahan yang signifikan. Menjamurnya tempat-tempat hangout dan ajang kumpul-kumpul bersama teman dan komunitas semakin bermunculan, termasuk di Kota Tangerang.

Kota Tangerang merupakan salah satu kota metropolitan di Jakarta Raya atau kawasan Jabodetabek. Bersama dengan Jakarta, Bogor, Depok, dan Bekasi, Tangerang juga terkenal atas kepadatan penduduknya. Lokasi geografis Tangerang yang sangat dekat dengan ibukota DKI Jakarta, menjadikan banyak warga Tangerang yang bepergian ke Jakarta hanya untuk sekedar nongkrong atau hangout dengan teman atau komunitasnya. Di Jakarta, sebagai contoh, setidaknya terdapat lebih dari 300 kafe yang beroperasi. ${ }^{7}$

Merebaknya kafe memang sudah menjadi hal lumrah di Jabodetabek. ${ }^{8}$ Beragam kafe yang ada menawarkan berbagai macam fasilitas menarik dan budget yang beragam menjadi daya tarik tersendiri dan sangat diminati oleh berbagai macam kalangan. Umumnya kafe digunakan sebagai wadah untuk tempat bertatap muka atau nongkrong baik dengan keluarga, teman, atau partner bisnis. Sebagai akibatnya, nongkrong atau hangout menjadi sangat lumrah bagi kehidupan malam masyarakat Jabodetabek. Di sisi lain, saat ini di Tangerang pun sudah menjamur banyak tempat nongkrong yang tidak kalah modern dengan Jakarta.

Masyarakat dari berbagai kalangan mampu memilih tempat nongkrong sesuai dengan selera dan budget mereka hanya untuk sekedar kongkow melepas penat. Sudah banyak tempat di Tangerang yang menyediakan tempat yang nyaman dan kekinian, makanan dan minuman yang enak, dan Instagramable. Di antara yang direkomendasikan sebagai tempat nongkrong yang populer di Tangerang adalah Sabeb Café, Lot 9 Café \& Restaurant, Aeon Sushi, Hammock Café, Kafe Rute 15, Kakolait Café, Rati Bakar 88, Cascara Coffee, Travel Mie Tangerang, Intro Jazz Bistro and Café, Carburator Spring Café, Alun-alun Tangerang, Asagao Cafee Haouse, Downtown Walk Summarecon Mall Serpong, Café Nibbles, Industrie Café, Flavor Bliss, Eureca Resto and Café, Bintaro 9 Walk, The Republic of Burger, dan Bong Kopitown. ${ }^{9}$ Oleh karena itu,

\footnotetext{
${ }^{5}$ William B Gudykunst, Young Yun Kim, and Burr Ridge, "Third Edition Communicating With Strangers an Approach To Intercultural Communication," in Communicating with Strangers (Boston: Mc Graw Hill, 1997).

6 Andrian Listyo Guritno, "Adaptasi Sosial Mahasiswa Rantau Dalam Dunia Hiburan Malam (Studi Deskriptif Tentang Adaptasi Sosial Mahasiswa Rantau Jakarta Dalam Dunia Hiburan Malam Di Kota Surabaya)" (Universitas Airlangga, 2018).

${ }^{7}$ Ahmad Fauzi, I Nengah Punia, and Gede Kamajaya, "Budaya Nongkrong Anak Muda Di Kafe (Tinjauan Gaya Hidup Anak Muda Di Kota Denpasar),” Jurnal Ilmiah Sosiologi (SOROT) 3, no. 5 (2017): 40-47.

${ }^{8}$ Fauzi, Punia, and Kamajaya.

${ }^{9}$ Zona Makan, "21 Tempat Nongkrong Di Tangerang Paling Hitz Banget," n.d.
} 
dengan fenomena ini tanpa disadari bahwa nongkrong telah menjadi bagian kehidupan masyarakat dimana masyarakat menjadi sangat bergantung dengan kegiatan nongkrong di kafe. ${ }^{10}$

Begitu banyak pilihan tempat kongkow dengan menawarkan berbagai macam fasilitas yang menarik dan aneka macam menu makanan dapat membuat masyarakat betah untuk mengobrol berlama-lama. Dalam kegiatan nongkrong, mereka dapat bertemu lebih banyak orang dan mengerti karakter yang dimiliki oleh orang lain. Kafe merupakan tempat bersantai dan berbincang dengan teman sejawat tentang banyak hal. Nongkrong dan berbincang bersama komunitas sudah menjadi kebutuhan. Dalam kegiatan menongkrong, biasanya ada kegiatan foto bersama yang kemudian diunggah ke media sosial, dimana hal tersebut terkadang untuk sekedar menunjukkan eksistensi dan mencari pujian.

Kebiasaan suka berkumpul memang sangat melekat dalam budaya di Indonesia yang masih memiliki kehidupan sosial yang sangat kuat, jika dibandingkan dengan budaya Barat yang cenderung individualistis. Tidak heran jika di Indonesia tempat-tempat kongkow sangat beragam. ${ }^{11}$ Hal ini juga sejalan dengan kondisi Indonesia yang multikultural, diperlukan landasan fundamental untuk berpikir, melakukan aktivitas bernegara yang bertujuan untuk menghilangkan penindasan dan berkeinginan untuk mewujudkan perdamaian di Indonesia hingga mampu membuat tatanan sosial berjalan dengan baik. ${ }^{12}$ Di sisi lain, terdapat dampak negatif dari munculnya berbagai macam kafe yang menawarkan suasana nyaman untuk berdiskusi ataupun nongkrong ini, yakni sangat mungkin membuka peluang untuk bergunjing, gosip, atau gibah.

Dalam penelitian ini, peneliti akan menjabarkan peran manusia dalam masyarakat sehingga dapat menimbulkan adanya gosip. Umumnya gosip dianggap dapat menimbulkan hal negatif bagi masyarakat, tetapi penelitian ini berangkat dari asumsi bahwa terdapat hal positif dari gosip. Vohs et al menyatakan bahwa gosip adalah bagian dari proses pembelajaran yang memungkinkan seseorang untuk belajar dari pengalaman orang lain. ${ }^{13}$ Oleh karena itu, gosip merupakan dinamika sosial yang tidak selalu berperan negatif tetapi juga positif karena dapat mendorong pengendalian sosial di tengah masyarakat. ${ }^{14}$

\section{Metode}

Peneliti menggunakan pendekatan kualitatif dalam melakukan penelitian ini. Dengan melakukan studi kasus, peneliti berharap dapat memberikan gambaran yang menyeluruh dan mendalam tentang penelitian yang dilakukan. Teknik pemilihan informan dilakukan dengan menggunakan metode purposive sampling yang artinya informan ditentukan secara sengaja atas pertimbangan tertentu, bukan secara acak. ${ }^{15}$ Total jumlah informan dalam penelitian ini adalah 15 orang

\footnotetext{
${ }^{10}$ Fauzi, Punia, and Kamajaya, "Budaya Nongkrong Anak Muda Di Kafe (Tinjauan Gaya Hidup Anak Muda Di Kota Denpasar)."

${ }^{11}$ Handi Irawan, 10 Prinsip Kepuasan Pelanggan (PT Elex Media Komputindo, 2002).

12 Abu Muslim, "Relevansi Nalar Humanisme Jhon Locke terhadap Persoalan Keanekaragaman Indonesia," Al-Adabiya: Jurnal Kebudayaan Dan Keagamaan 13, no. 01 (September 3, 2018): 144-58, https://doi.org/10.37680/adabiya.v13i01.8.

13 Roy F. Baumeister, Liqing Zhang, and Kathleen D. Vohs, "Gossip as Cultural Learning," Review of General Psychology 8, no. 2 (2004): 111-21, https://doi.org/10.1037/1089-2680.8.2.111.

${ }^{14}$ Roucek Waren, Pengendalian Sosial (Jakarta: PT Rajawali, 1996).

${ }^{15}$ Sanapiah Faisal, Penelitian Kualitatif: Dasar-Dasar Dan Aplikasi (Malang: Ikip Malang, 1990).
} 
masyarakat yang berkunjung ke 3 cafe sasaran (Aviators Coffee Budiarto, Fiftyfeet Coffee, dan Café Bakul Liwet yang kesemuanya beralamatkan di Kec. Legok, Tangerang, Banten).

Peneliti melakukan wawancara di kafe yang sudah ditentukan dalam kurun waktu bulan Januari hingga Maret 2021 dan melakukan interviu terhadap beberapa informan dengan menanyakan pertanyaan seperti "Apakah Anda suka nongkrong di kafe?", "Bagaimana pendapat Anda dengan orang-orang yang nongkrong di kafe sambil bergosip?" dan "Mengapa Anda berpendapat seperti itu?"

\section{Hasil dan Pembahasan}

\section{Manusia sebagai Makhluk Sosial}

Aristoteles mengkategorikan manusia ke dalam "zoon politicon" yang artinya manusia adalah makhluk yang ingin selalu bergaul dan berkumpul. Dalam kehidupan sehari-hari, manusia selalu membutuhkan orang lain dan menjadi bagian dari masyarakat serta lingkungannya. Oleh karena itu, manusia merupakan makhluk yang bermasyarakat. Karena sifat suka bergaul dan bermasyarakat itulah manusia dikenal sebagai makhluk sosial.

Dalam kehidupan sehari-hari, manusia di semua kalangan strata sosial tidak dapat hidup sendiri atau mencukupi kebutuhan sendiri. Selebritis Raffi Ahmad, sebagai contohnya, merupakan public figure yang sudah tidak dipertanyakan lagi kekayaannya masih memerlukan asisten di dalam kehidupan sehari-hari guna membantu kelancaran pekerjaannya. Hal tersebut dikarenakan profesi dan kekayaan seseorang tidak mempengaruhi manusia untuk tidak membutuhkan manusia lain. Setiap individu pasti membutuhkan komunikasi, interaksi, dan sosialisasi dengan manusia lain. Mereka berinteraksi satu dengan yang lain, baik dengan kerabat lain, lingkungan sosialnya, seperti tetangga, teman sejawat, komunitasnya, peer group, arisan, dan lain-lain yang mempengaruhi individu. ${ }^{16}$

Allah Swt. menciptakan manusia dalam bentuk yang sebaik-baiknya. Manusia mempunyai bentuk fisik yang sempurna daripada makhluk ciptaan Tuhan yang lain. Selain itu manusia memiliki kondisi fisik dan psikis terbaik, sebagaimana dikutip dari QS. at-Tin. Secara fisik, manusia diberi anugerah oleh Allah Swt. berupa lidah. Dengan lidah, manusia dapat berkomunikasi dengan sesama menggunakan bahasa. Kemampuan komunikasi manusia jauh lebih baik jika dibandingkan dengan makluk ciptaan Allah Swt. yang lain. Dalam kegiatan dasar manusia, komunikasi merupakan suatu proses sosial yang menimbulkan interaksi manusia sehingga dapat dikatakan komunikasi merupakan bagian dari kehidupan sehari-hari.

Komunikasi antar manusia dapat memberikan dampak positif dan negatif bagi penggunanya. Salah satu hal positif dari komunikasi adalah dapat membangun kepercayaan diri di lingkungannya. Melalui komunikasi, manusia dapat menyampaikan informasi mengenai peristiwa yang sedang terjadi sehingga dapat memberikan pengetahuan kepada orang lain. Sebagai contohnya, pembawa berita di TV menyampaikan informasi bahwa ada musibah di kota lain.

\footnotetext{
${ }^{16}$ Selo Soemardjan, Setangkai Bunga Sosiologi (Jakarta: Fakultas Ekonomi Universitas Indonesia, 1974).
} 
Dengan berkomunikasi, manusia dalam kehidupan sehari-hari dapat saling berinteraksi dan berhubungan satu dengan lainnya baik itu secara individu ataupun berkelompok. Dalam hal ini, manusia dapat bertukar pikiran dan berbagi rasa baik secara langung atau tidak langsung. Kebutuhan manusia akan kasih sayang, penerimaan di lingkungan dan komunitas merupakan kebutuhan sosialnya. ${ }^{17}$

Salah satu contoh bentuk komunikasi dalam kehidupan sehari-hari adalah gosip. Gosip merupakan media untuk mendapatkan informasi tentang hal lain dan dapat mempererat ikatan sosial. ${ }^{18}$ Melalui gosip, masyarakat dapat bertukar informasi yang ada di dalam kehidupan seharihari atau di dalam komunitasnya. Dalam hal ini, gosip dapat menjaga erat hubungan antar manusia. ${ }^{19}$ Hubungan erat dapat terjalin dengan baik antara si penggosip dan si pendengar dalam mengisi waktu dan berbagi informasi satu sama lain.

Saat ini, gosip merupakan fenomena sehari-hari di masyarakat, khususnya Indonesia. Semua kalangan masyarakat menyukai acara gosip. Masyarakat dipandang lebih tertarik mendengar berita buruk mengenai apapun daripada berita baiknya. Hal tersebut sejalan dengan pendapat Baumeister, Zhang, \& Vohn, "bad may be stronger than good in general because it is more important and more adaptive to learn about danger". ${ }^{20}$ Ketika seseorang membicarakan hal buruk lalu ada pihak lain yang mengetahui berita tersebut, maka ini dapat menjadi informasi yang menarik. Berbanding terbalik ketika ada pihak yang menyampaikan ada orang lain yang berbuat baik dengan mematuhi norma, maka terkadang dianggap berita yang tidak menarik atau biasabiasa saja. ${ }^{21}$ Di Indonesia, acara gosip atau infotainment ditayangkan oleh hampir semua stasiun televisi, sebagaimana tampak dalam cuplikan daftar acara beberapa stasiun televisi pada tanggal 10 April 2021 di Tabel 1.22

Tabel 1. Daftar Acara Infotainment di Televisi

\begin{tabular}{|c|c|c|c|c|c|c|}
\hline \multirow[t]{2}{*}{ No } & \multirow{2}{*}{$\begin{array}{l}\text { Stasiun } \\
\text { TV }\end{array}$} & \multirow[t]{2}{*}{ Infotainment Gosip } & \multicolumn{3}{|c|}{ Jam Tayang } & \multirow{2}{*}{$\begin{array}{l}\text { Waktu } \\
\text { (WIB) }\end{array}$} \\
\hline & & & Pagi & Siang & Sore & \\
\hline \multirow[t]{2}{*}{1} & \multirow[t]{2}{*}{ RCTI } & Go spot & $\sqrt{ }$ & & & 6.15 \\
\hline & & Silet & $\sqrt{ }$ & & & 9.45 \\
\hline \multirow[t]{3}{*}{2} & TransTV & Insert Pagi & $\sqrt{ }$ & & & 6.30 \\
\hline & \multirow{3}{*}{ SCTV } & Insert Siang & & $\sqrt{ }$ & & 11.30 \\
\hline & & Insert Investigasi & & & $\sqrt{ }$ & 18.00 \\
\hline 3 & & Hot Shot & $\sqrt{ }$ & & & 6.00 \\
\hline \multirow[t]{4}{*}{4} & \multirow[t]{4}{*}{ Trans 7} & Selebrita Pagi & $\sqrt{ }$ & & & 7.00 \\
\hline & & $\begin{array}{l}\text { Selebrita On the } \\
\text { Weekend }\end{array}$ & & $\sqrt{ }$ & & 11.00 \\
\hline & & Seleb Expose & & & $\sqrt{ }$ & 17.15 \\
\hline & & On the Spot & & & $\sqrt{ }$ & 18.00 \\
\hline
\end{tabular}

${ }^{17}$ Ashar Sunyoto Munandar, Psikologi Industri Dan Organisasi (Jakarta: Universitas Indonesia (UI-Press), 2001).

${ }^{18}$ Robin M. "Robin Dunbar Queen, Grooming, Gossip, and the Evolution of Language (Cambridge: Harvard University Press, 1996), https://doi.org/doi:10.1017/S0047404500019898.

19 Sandy Chua and Kristine June Uy, "The Psychological Anatomy of Gossip," Recoletos Multidisciplinary Research Journal 1, no. 1 (2013): 41-47, https://doi.org/10.32871/rmrj1301.01.05.

${ }^{20}$ Baumeister, Zhang, and Vohs, "Gossip as Cultural Learning."

${ }^{21}$ Baumeister, Zhang, and Vohs.

22 “Jadwal Acara TV Hari Ini, Sabtu 10 April 2021: Ikatan Cinta Di RCTI Hingga Cliffhanger Di GTV Halaman All - Tribun Banten,” TribunBanten.com, 2021. 
Berdasarkan Tabel 1, dalam satu hari ada sekurangnya 10 acara infotainment pada empat stasiun televisi saja; belum termasuk di stasiun televisi lainnya. Acara tersebut dimulai pagi hari hingga sore hari. Aktivitas menonton acara gosip mempunyai tujuan tersendiri bagi semua kalangan masyarakat tertentu. Aktivitas tersebut mempunyai tujuan dan perilaku itu pada umumnya dimotivasi oleh keinginan untuk memperoleh tujuan yakni membicarakan kejadian yang sudah terjadi atau untuk mendapatkan hiburan. Sejalan dengan mereka yang tidak mempunyai kegiatan yang menarik, waktu luang yang banyak maka mereka akan sangat menikmati kegiatan gosip. Oleh karena itu, gosip adalah kegiatan yang sangat menyenangkan dan menghibur. ${ }^{23}$ Dalam masyarakat, bergosip untuk mendapatkan kesenangan belaka, bukan untuk tujuan tertentu. Kesenangan ini yang membuat orang-orang sangat nyaman terlibat dalam percakapan yang mengandung gosip. Acara gosip yang tersedia menjadi refleksi keingintahuan terhadap orang lain seperti perilaku, kehidupan sehari-hari, dan juga kepemilikan.

Perilaku hobi mengikuti acara gosip yang ada di masyarakat sejalan dengan interaksi sosial dimana banyak orang kemudian bergosip karena ingin mendapatkan informasi. Apabila dua orang atau lebih bertemu, interaksi sosial dimulai saat itu juga. Mereka saling sapa, berjabat tangan, atau mungkin saling berdebat. Interaksi yang terjadi antar individu atau kelompok membawa gosip sebagai alat yang menarik dan media yang mempermudah individu atau kelompok untuk berbaur. Seperti yang dinyatakan oleh Kurland dan Pelled bahwa gosip mampu membuat seseorang mempunyai pergaulan yang luas di suatu komunitas. ${ }^{24}$

Adanya kontak sosial dimana manusia saling bertemu atau bersama-sama seperti berbicara dengan tatap muka di tempat-tempat umum seperti kafe membuat manusia tidak dapat menghindar dari tindakan gosip. Komunikasi yang terjalin antar sesama manusia dan ada timbal balik dari kedua belah pihak dapat memancing adanya topik pembicaraan yang sedang hits di lingkungannya. Membicarakan hal lain atau orang lain merupakan sifat dasar manusia sebagai makhluk sosial yang berinteraksi. Seperti yang dinyatakan oleh Baumeister, et al, "looking at a cultural perspective, gossip can be a means for us to learn about our social environment". ${ }^{25}$ Bagi sebagian orang yang memasuki lingkungan baru yang lebih luas jangkauannya sangat membutuhkan banyak informasi agar dapat menyesuaikan diri dengan lingkungannya. Setiap orang yang menjalani proses sosialisasi akan mengerti bagaimana cara bertingkah laku di tengah masyarakat sehingga mampu untuk menjadi masyarakat yang mengerti norma. Dapat dikatakan bahwa gosip merupakan salah satu cara belajar peraturan sosial yang ada.

\section{Potensi Negatif Gosip dalam Masyarakat}

Gosip merupakan fenomena di masyarakat saat ini yang identik dengan hal buruk atau perbuatan negatif. Persepsi umum yang ada di masyarakat tentang gosip adalah "obrolan ringan", "obrolan toko", "obrolan kosong", bahkan "fitnah". ${ }^{26}$ Biasanya gosip diawali oleh rumor atau desas desus atau kabar angin yang belum tentu benar kebenarannya. Pengamat politik dari Universitas Gajah

${ }^{23}$ Dana Turcotte, "Gossip and the Group: A Self-Categorization Perspective," CGU Thesis and Dissertations, 2012, 94, https://doi.org/10.5642/cguetd/30.

${ }^{24}$ Chua and Uy, "The Psychological Anatomy of Gossip."

${ }^{25}$ Baumeister, Zhang, and Vohs, "Gossip as Cultural Learning."

${ }^{26}$ Chua and Uy, "The Psychological Anatomy of Gossip." 
Mada, Pratikno, mengaitkan bahwa rumor, isu, atau desas-desus yang dikemas sedemikian menarik dengan sebutan gosip yang katanya "digosok makin sip". ${ }^{27}$

Semua orang baik laki-laki maupun perempuan di semua kalangan gemar bergosip. Mereka yang mengaku anti terhadap gosip, bisa jadi sebetulnya tetap pasang telinga ketika ada gosip yang menarik tentang orang lain atau idolanya. Gosip seringkali tidak ada gunanya, hanya membuang waktu saja, dan berdampak buruk. Tetapi, pada kenyataannya sangat sulit menghentikan kebiasaan gibah karena setiap orang berkontribusi dalam bergosip dan sangat sulit untuk menghindar dari gosip..$^{28}$

Di sisi lain, potensi resiko adanya konflik terbuka lebar jika seseorang mengetahui jika dirinya sedang dibicarakan. Konflik yang muncul adalah hubungan antara penggosip dengan target gosip menjadi buruk. Orang melakukan gosip sudah pasti menceritakan tentang tingkah laku orang lain yang bersifat negatif. ${ }^{29}$ Ucapan yang muncul mengandung kebencian maka dapat melukai perasaan orang lain dengan perkataan. Sebegitu hebatnya dampak dari ucapan seseorang yang dapat melukai hati, maka peribahasa "lidah tak bertulang namun bisa lebih tajam daripada pedang" sangat cocok menggambarkan kondisi tersebut.

Dalam sebuah penelitian yang dilakukan oleh Hafizah, beberapa jenis dampak yang ditimbulkan dalam kehidupan sehari-hari adalah terjadinya perceraian dalam rumah tangga dimana sang istri terpengaruh oleh hasutan orang lain, terjadinya kesalahpahaman antar sesama penduduk, dan warga yang digosipkan tidak ingin melakukan kontak dengan warga sekitar. Lebih jauh lagi, masyarakat akan takut bertatap muka dengan ibu-ibu yang suka bergosip. ${ }^{30}$

\section{Gosip sebagai Kontrol Sosial}

Ada sisi positif dan negatif dalam kehidupan, begitu pula dengan gosip yang ternyata juga mempunyai sisi positif bagi masyarakat. Gosip dapat memberikan keuntungan bagi siapa saja yang melakukannya. Sebagai contohnya pegawai kantoran yang memiliki kehidupan monoton, terkadang disebut memerlukan sentuhan gosip untuk menghindarkan kejenuhan dan menghidupkan suasana.

Seorang ahli menyatakan bahwa gosip merupakan wadah untuk diskusi mengenai topik sosial. Gosip merupakan kelebihan dalam pergaulan sosial, bukan merupakan kekurangan yang harus dihindari. Ia menyatakan bahwa gosip menyumbang sekitar $65 \%$ dari bahan pembicaraan saat orang-orang sedang berada di tempat umum. ${ }^{31}$ Dua orang atau lebih jika bertemu akan membicarakan hal-hal sepele hingga pada tahap isu skandal yang ada di lingkungannya sebagai bahan pembicaraan. Oleh karena itu, gosip yang merupakan bagian dari komunikasi dimana hal tersebut adalah bagian dari upaya manusia untuk memenuhi kebutuhan. ${ }^{32}$

27 Hafizah, "Gosip Di Kalangan Ibu-Ibu Rumah Tangga," Historia: Jurnal Program Studi Pendidikan Sejarah 4, no. 1 (2019): 11-18.

${ }^{28}$ Chua and Uy, "The Psychological Anatomy of Gossip."

${ }^{29}$ Baumeister, Zhang, and Vohs, "Gossip as Cultural Learning."

${ }^{30}$ Hafizah, "Gosip Di Kalangan Ibu-Ibu Rumah Tangga."

${ }^{31}$ R. I.M. Dunbar, Anna Marriott, and N. D.C. Duncan, "Human Conversational Behavior," Human Nature 8, no. 3 (1997): 231-46, https://doi.org/10.1007/BF02912493.

${ }^{32}$ Eko A Meinarno, Sunu Bagaskara, and Mely Putri Kurniati Rosalina, “Apakah Gosip Bisa Menjadi Kontrol Sosial?," Jurnal Psikologi Pitutur 1, no. 2 (2011): 78-84. 
Dalam kehidupan nyata di lingkungan tempat kerja, sebagai contoh, rumor mengenai partner kerja yang dipecat merupakan hal yang menarik untuk dibahas dan lebih penting dibanding cerita soal karyawan yang berprestasi. Pelaku gosip memiliki kecenderungan untuk melakukan perbandingan dan evaluasi sosial. Evaluasi dalam aktifitas bergosip dapat membantu individu untuk melakukan penyesuaian diri dengan lingkungan yang diharapkan dapat beradaptasi dengan norma masyarakat atau lingkungan tempat tinggal atau lingkungan kerja. Hal tersebut membantu manusia belajar dari kesalahan dan meniru kesuksesan orang lain.

Dengan demikian, gosip menjadi penting untuk kehidupan sosial karena bisa memberikan informasi yang berharga. ${ }^{33}$ Mengetahui informasi tentang orang lain merupakan cara paling efisien untuk memantau orang lain bekerjasama dalam mewujudkan tujuan utama, atau mengenali dan menghukum mereka yang tidak bisa bekerjasama. Aktivitas gosip yang terjadi di masyarakat merupakan hal yang sangat mudah dilakukan guna mendapatkan informasi tentang seseorang daripada harus bertemu langsung dengan sang target tersebut. Perbandingan sosial yang dinilai adalah kemampuan seseorang yang lebih baik atau lebih jelek dari norma di masyarakat. Apabila seseorang merasa melakukan hal yang lebih baik dari si target gosip, maka ia akan mempromosikan diri tetapi jika sikapnya lebih buruk dari si target gosip, maka ia akan memperbaiki diri.

Melalui gosip, masyarakat yang melanggar norma dan ketentuan masyarakat dapat menerima hukuman sosial sebagai akibatnya. Boyd menyatakan bahwa gosip dibuat untuk menguntungkan diri sendiri, maka kebiasaan itu melanggar norma kerja sama. Penggosip akan dicela, tetapi jika gosip itu baik dan dapat menguntungkan banyak orang, maka mereka akan dihormati. $^{34}$

Dengan adanya gosip, setiap individu dapat memahami peran dan tingkah laku yang diharapkan darinya oleh masyarakat. Di sisi lain, gosip mampu memberi pelajaran kepada setiap individu untuk menjadi pribadi yang diterima dan menghindari hal-hal yang tidak disukai oleh lingkungan. ${ }^{35}$ Hal-hal positif dari gosip mendorong dan menyadarkan masyarakat bahwa suatu hal yang dilakukan tidak disukai oleh kalangan tertentu sehingga gosip dapat dijadikan sebagai alat pengendalian sosial.

\section{Gaya Hidup Nongkrong di Kafe dan Perilaku Gosip}

Dari 15 orang informan menyatakan tidak masalah dengan hal menongkrong di kafe sambil bergosip. Mereka tentu mempunyai banyak alasan untuk itu. Berikut merupakan pernyataan yang terpilih. Para informan ditanya tentang pertanyaan tentang orang yang menongkrong di café dengan bergosip, salah satunya terungkap sebuah pernyataan dari informan perempuan ( 25 tahun, Aviators Coffee, pukul 17.00) bahwa fungsi gosip adalah sebagai hiburan:

“.....Yaa kita sudah kerja seharian, capek, dan setres. Untuk hilangkan penat sama tementemen nongkrong sambil makan malam. Ngobrol macam-macam, bisa sampai ketawaketawa. Rasanya puas banget lah."

\footnotetext{
${ }^{33}$ Baumeister, Zhang, and Vohs, "Gossip as Cultural Learning."

34 Jessica Dore, "Ternyata Kebiasaan Bergosip Berperan Penting Atas Kelangsungan Hidup Manusia," vice.com, n.d.

${ }^{35}$ Baumeister, Zhang, and Vohs, "Gossip as Cultural Learning."
} 
Adapun informan laki-laki (30 tahun, Café Bakul Liwet, pukul 19.00), sesuai pernyataannya beranggapan bahwa gosip dapat digunakan sebagai alat untuk pertukaran informasi. Hasil wawancara dengan informan sebagai berikut:

"Gue punya grup mobil great corolla. Biasanya 1 minggu 2 kali kita kumpul bareng di café. Sekalian santai-santai makan di café. Di café banyak hiburan. Awalnya gue ga ngerti apaapa tentang mobil. Tapi karena gabung di grup mobil great corolla sedikit banyak paham tentang seluk beluk mobil, bahkan kita punya langganan bengkel sendiri khusus untuk mobil-mobil great corolla."

Informan perempuan (29 tahun, Café Bakul Liwet, pukul 16.00) menyatakan bahwa gosip dapat digunakan sebagai sarana menambah dan mempererat pertemanan. Hasil wawancara sebagai berikut:

"Aku bisa dapat temen baru dari nongkrong di café. Waktu itu ga sengaja ketemu temen di café, dan aku dikenalin sama temennya temen aku. Dari pertemuan yang ga sengaja akhirnya kita rutin ketemuan karena nyambung obrolan kita. Kebetulan kita sama-sama ibu rumah tangga. Dia udah punya satu anak sedangkan aku lagi hamil anak pertama. Jadi aku bisa banyak nanya tentang pengalaman dia."

Informan perempuan (35 tahun, Fiftyfeet Café, pukul 14.00), sesuai dengan pernyataannya bahwa gosip dapat digunakan sebagai alat untuk konsultasi dan mempengaruhi. Hasil wawancara sebagai berikut:

"Saya seorang ibu rumah tangga dan biasanya dalam 1 minggu memiliki me-time $2 x$. biasanya dalam menghabiskan waktu saya ngumpul dengan geng arisan di café. Di sana kita saling curhat masalah masing-masing dan kadang dari kegiatan arisan ini, kita dapat solusi yang diinginkan. Pernah waktu itu ada kejadian saya mau cerai dan temen-temen geng nasehatin untuk tidak melakukan hal itu. Mereka menyarankan banyak hal, seperti banyak menghabiskan waktu dengan suami atau mulai untuk menjalin komunikasi yang baik dan tidak mengedepankan ego. Dari nasehat itu, akhirnya pelan-pelan saya dapat memperbaiki hubungan dengan suami."

\section{Kesimpulan}

Gaya hidup menongkrong di kafe sudah menjadi hal yang lumrah di semua kalangan masyarakat. Dengan nongkrong, setiap orang dapat bersantai menghilangan kejenuhan setelah bekerja dan dapat bercengkerama dengan kolega kerja atau keluarga. Berkumpul-kumpul atau bersosialisasi adalah salah satu ciri dari manusia sebagai makluk sosial dimana manusia membutuhkan orang lain.

Talking to other people merupakan sifat dasar manusia sebagai makhluk sosial yang berinteraksi. Komunikasi yang terjalin antara manusia satu dengan yang lain kadang kala menimbulkan obrolan yang ngalor ngidul yang menyebabkan adanya berita-berita yang belum tentu kebenarannya. Dari sini, aktivitas gosip kemudian menjadi tidak dapat terhindarkan ketika adanya aktivitas nongkrong. Gosip merupakan kegiatan yang menyenangkan dan menghibur, namun di sisi lain ia juga dapat berperan sebagai sarana berbagi informasi maupun konsultasi, bahkan dapat menjadi alat untuk melakukan kontrol sosial. 


\section{Daftar Pustaka}

Baumeister, Roy F., Liqing Zhang, and Kathleen D. Vohs. "Gossip as Cultural Learning.” Review of General Psychology 8, no. 2 (2004): 111-21. https://doi.org/10.1037/1089-2680.8.2.111.

Chua, Sandy, and Kristine June Uy. "The Psychological Anatomy of Gossip." Recoletos Multidisciplinary Research Journal 1, no. 1 (2013): 41-47. https://doi.org/10.32871/rmrj1301.01.05.

Dore, Jessica. "Ternyata Kebiasaan Bergosip Berperan Penting Atas Kelangsungan Hidup Manusia." vice.com, n.d.

Dunbar, R. I.M., Anna Marriott, and N. D.C. Duncan. "Human Conversational Behavior." Human Nature 8, no. 3 (1997): 231-46. https://doi.org/10.1007/BF02912493.

Faisal, Sanapiah. Penelitian Kualitatif: Dasar-Dasar Dan Aplikasi. Malang: Ikip Malang, 1990.

Fauzi, Ahmad, I Nengah Punia, and Gede Kamajaya. "Budaya Nongkrong Anak Muda Di Kafe (Tinjauan Gaya Hidup Anak Muda Di Kota Denpasar).” Jurnal Ilmiah Sosiologi (SOROT) 3, no. 5 (2017): 40-47.

Gudykunst, William B, Young Yun Kim, and Burr Ridge. "Third Edition Communicating With Strangers an Approach To Intercultural Communication." In Communicating with Strangers. Boston: Mc Graw Hill, 1997.

Guritno, Andrian Listyo. “Adaptasi Sosial Mahasiswa Rantau Dalam Dunia Hiburan Malam (Studi Deskriptif Tentang Adaptasi Sosial Mahasiswa Rantau Jakarta Dalam Dunia Hiburan Malam Di Kota Surabaya).” Universitas Airlangga, 2018.

Hafizah. "Gosip Di Kalangan Ibu-Ibu Rumah Tangga." Historia: Jurnal Program Studi Pendidikan Sejarah 4, no. 1 (2019): 11-18.

Herlyana, Elly. "Fenomena Coffee Shop Sebagai Gejala Gaya Hidup Baru Kaum Muda."

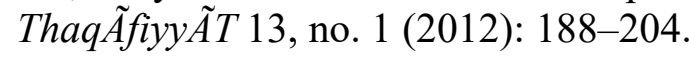

Irawan, Handi. 10 Prinsip Kepuasan Pelanggan. PT Elex Media Komputindo, 2002.

TribunBanten.com. "Jadwal Acara TV Hari Ini, Sabtu 10 April 2021: Ikatan Cinta Di RCTI Hingga Cliffhanger Di GTV - Halaman All - Tribun Banten,” 2021.

Juni Priansa, Donni. Perilaku Konsumen Dalam Persaingan Bisnis Kontemporer. Bandung: Alfabeta, 2017.

Kropotkin, Petr. "Ethics : Origin and Development," 1-138. London: George G. Harrap and Co., LTD., London, Calcutta, and Sydney 1924., 1922. https://doi.org/10.1130/spe164-p1.

Makan, Zona. "21 Tempat Nongkrong Di Tangerang Paling Hitz Banget,” n.d.

Meinarno, Eko A, Sunu Bagaskara, and Mely Putri Kurniati Rosalina. "Apakah Gosip Bisa Menjadi Kontrol Sosial?” Jurnal Psikologi Pitutur 1, no. 2 (2011): 78-84.

Munandar, Ashar Sunyoto. Psikologi Industri Dan Organisasi. Jakarta: Universitas Indonesia (UI-Press), 2001.

Muslim, Abu. "Relevansi Nalar Humanisme Jhon Locke Terhadap Persoalan Keanekaragaman Indonesia." Al-Adabiya: Jurnal Kebudayaan Dan Keagamaan 13, no. 01 (September 3, 2018): 144-58. https://doi.org/10.37680/adabiya.v13i01.8.

Pratiwi, Ananda Vidyaratri Mega, and Rizki Amalia Sholihah. "Evolusi Dan Eksistensi Model Abaya Pada Masa Modern Di Jazirah Arab." Al-Adabiya: Jurnal Kebudayaan Dan Keagamaan 15, no. 02 (December 12, 2020): 229-41. https://doi.org/10.37680/adabiya.v15i02.620. 
Queen, Robin M. "Robin Dunbar. Grooming, Gossip, and the Evolution of Language. Cambridge: Harvard University Press, 1996. https://doi.org/doi:10.1017/S0047404500019898.

Soemardjan, Selo. Setangkai Bunga Sosiologi. Jakarta: Fakultas Ekonomi Universitas Indonesia, 1974.

Turcotte, Dana. "Gossip and the Group: A Self-Categorization Perspective." CGU Thesis and Dissertations, 2012, 94. https://doi.org/10.5642/cguetd/30.

Waren, Roucek. Pengendalian Sosial. Jakarta: PT Rajawali, 1996. 